\title{
First RECORD OF A HUMPBACK WHALE (MEGAPTERA NOVAEANGLIAE) MOTHER and calf inside Bahia Magdalena, Baja California Sur, Mexico
}

\author{
Héctor Pérez-Cortés M. ${ }^{1,2, *}$, Carlos A. Barrera A. ${ }^{1}$ and Francisco Ollervides ${ }^{2}$
}

The humpback whale (Megaptera novaeangliae) is a cosmopolitan species with strong migratory habits (Evans, 1987; Clapham, 2002). It is found in Mexico in winter when it breeds and calves. In the Mexican Pacific they congregate in three subregions (Figure 1 ) to conduct breeding activities: (1) the southern coast of the Baja California peninsula, (2) the mainland coast of Mexico from Mazatlan to Tehuantepec, including Isla Isabel and islas Tres Marías; and (3) the Revillagigedo Archipelago. They can also be found in the upper Gulf of California, although this zone does not constitute an important aggregation area (Urbán and Aguayo, 1987; Alvarez et al., 1990).

The occurrence of humpback whale breeding and calving areas in the Mexican Pacific was initially described in the 19th century (Scammon, 1874). Humpback whales feeding along the coast of California, Oregon and Washington migrate seasonally to the wintering areas in Mexico and Central America (Steiger et al., 1991; Calambokidis et al., 2000; Urbán et al., 2000; Calambokidis and Barlow, 2004). central part of the bay we observed a humpback whale cow-calf pair on several occasions in January 2004. This is the first record of a humpback whale cow-calf pair inside Magdalena Bay, Baja California Sur. On 17 January we observed the cow-calf pair for about 15 minutes, starting at 10:00 $\mathrm{h}$, from distances as close as $50 \mathrm{~m}$. This sighting was recorded at $24^{\circ} 34.05^{\prime} \mathrm{N}$ and $112^{\circ} 02.32^{\prime} \mathrm{W}$. During this time the female breached, showing its flippers. A second sighting occurred on 22 January at $24^{\circ} 35.53^{\prime} \mathrm{N}$ and $112^{\circ} 03.03^{\prime} \mathrm{W}$ and lasted about 20 minutes beginning at 13:55h; this time we observed the whales from a distance of about $20 \mathrm{~m}$.

Identification of the species was based on the presence of a small dorsal fin on the dorsal hump, extremely large flippers that were observed during the first sighting when the whale breached; and the low and bushy shape of the blow. The pair showed an evasive behavior swimming away from the vessel. We photographed the dorsal fin of both the cow and the calf; the event was also recorded on video. This sighting was recorded in an area with a depth of $15 \mathrm{~m}$ and water temperature of $13^{\circ} \mathrm{C}$.

The Bahia Magdalena lagoon complex is located between $24^{\circ} 20^{\prime} \mathrm{N}$ $-25^{\circ} 20^{\prime} \mathrm{N}$ and $111^{\circ} 30^{\prime} \mathrm{W}-112^{\circ} 10^{\prime} \mathrm{W}$. The complex includes the largest and deepest lagoon in Baja California. The area is a primary breeding and calving area for gray whales (Eschrichtius robustus) (Rice et al., 1981; Villa-Ramirez et al., 1982) and several systematic studies have been conducted on this species at this location (Fleischer and Contreras, 1986; Gardner and Chávez-Rosales, 2000; Ollervides, 2001) and continuing to the present (PérezCortés et al., 2004). Therefore, the coverage of these waters by marine mammal studies has been good. Though the area outside the bay is considered the northern limit of the winter range for humpback whales in Mexico (Urbán and Aguayo, 1987; Urbán et al., 1999) they have not been reported within the Bay complex.

While conducting studies on gray whales from small vessels in the

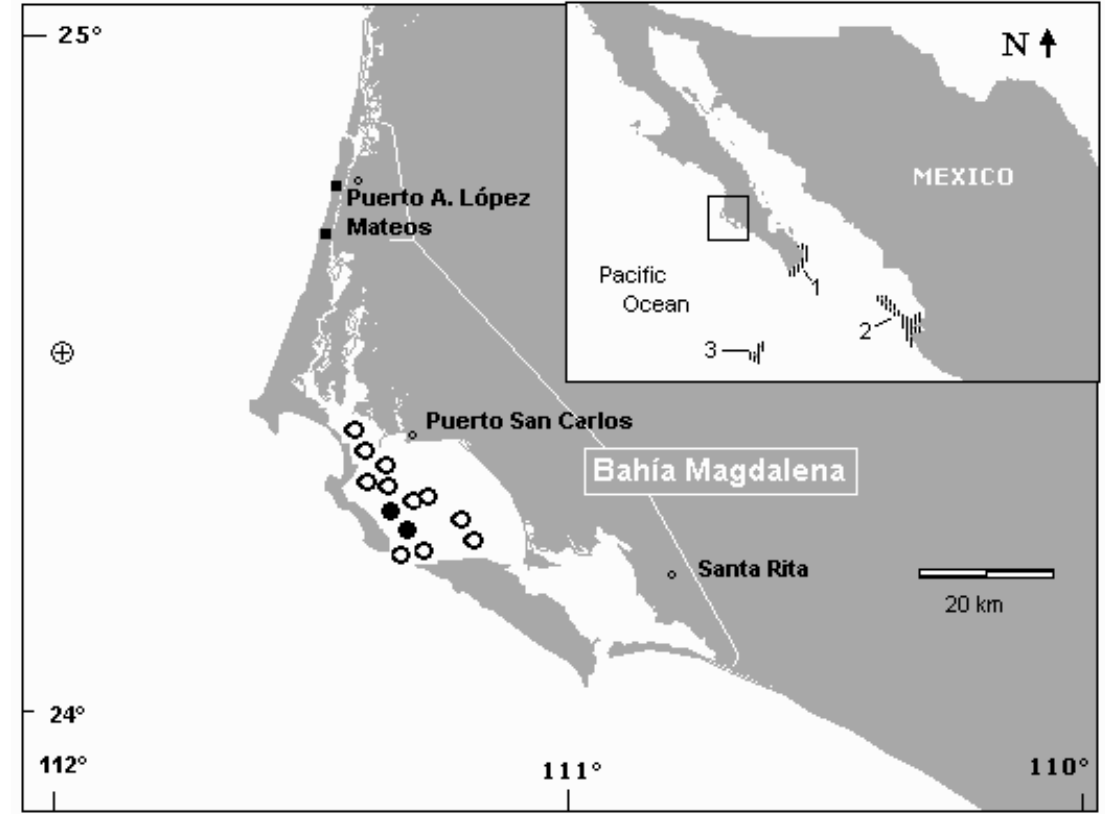

Figure 1. Humpback whales in Magdalena Bay, Baja California Sur. Cow-calf pair sightings reported here $(\bullet)$. Nearest and only known record of (nine) humpback whales in this area $(\oplus)$. Sightings of gray whales at the same dates as humpback whale cow-calf sightings (O). Recent strandings of humpback whales (1994 and 2003)(ש). Main breeding aggergations of humpback whales in the Mexican Pacific are shown in the inset: 1) Southern coast of Baja California; 2) Mainland coast of Mexico; and 3) the Revillagigedo Archipelago.

\footnotetext{
${ }^{1}$ Instituto Nacional de Ecología, SEMARNAT. Ocampo 1045 Col. Centro. 23000. La Paz, B.C.S.

2 SFS Center for Coastal Studies, México. A.P. 15. Pto. San Carlos, Baja California Sur, 23740

*Corresponding author, e-mail: hperez@fieldstudies.org
} 
Fishermen and whale watching operators told us about additional sightings in roughly this same period. Because only one pair was sighted each time, we believe that the cow-calf pair was the same during the different sightings.

The humpback cow-calf pair sighting locations are shown in Figure 1. The figure show sightings of gray whales recorded the same days; as well as a sighting of nine humpback whales recorded during a NOAA cruise in 1992 west of Magdalena Bay (2453.99N 112³6.61W) (Mangels and Gerrodette, 1994). The locations of two humpback whale strandings outside the bay at Magdalena Island are also shown. Of these one was recorded in spring 1994 and the other in fall 2003. In both cases the whales involved were young males.

One of us (Ollervides) has recorded the sounds of singing humpback whales near the entrance of the bay in the winters of 1998 and 1999. No visual confirmation was obtained at that time and the acoustic signals may have been produced at considerable distance.

Baleen whales occupy a wide variety of habitats. Behavioral flexibility in some species suggests they utilize a range of ecological situations (IWC, 1986). Some mysticetes, such as humpback and gray whales, tend to adhere to fairly well-defined migratory patterns. However, some individuals may occur in areas outside common aggregation zones (Martin and Reeves, 2002). Sightings of humpback whales have been documented in areas where they are not regularly found. Steiger et al. (1991) observed humpback whales at zones in Costa Rica where they were not present before.

Although we present only two sightings, these might suggest that a number of humpback whales are moving around the Bahia Magdalena region. Studies of the gray whale are conducted systematically in the area and previous to this event other baleen whales have not been recorded inside the bay, at least during the winter months.

\section{Acknowledgements}

We very much appreciate the kind advice and suggestions of Greg Silber and two anonymous reviewers who helped us improve the manuscript. We acknowledge the cooperation of Raymundo Vázquez Mejía, and the kind support of whale watching operators at Puerto San Carlos, particularly Crispín Mendoza from ULYSTUR, and Fito González from Magbay Tours. The map in Figure 1 was generated with Costas de México software (De la Cruz y Rodríguez, 2000).

\section{References}

Alvarez, C., Aguayo, A., Rueda, R. and Urbán, J. (1990) A note on the stock size of humpback whales along the Pacific Coast of Mexico. Pages 191-193 in Hammond, P.S., Mizroch, S. AND Donovan, G. (Eds) Individual Recognition of Cetaceans: Use of photo-identification. IWC, Cambridge, United Kingdom.
Calambokidis, J., Steiger, G.H., Rasmussen, K., Urbán-R., J., Balcomb, K.C., Ladrón de Guevara, P., Salinas, M., Jacobsen, J.K., BaKer, C.S., Herman, L.M., Cerchio, S. And Darling, J.D. (2000) Migratory destinations of humpback whales that feed off California, Oregon and Washingnton. Marine Ecology Progress Series 192: 295-304.

CAlambokidis, J. AND BARLOW, J. (2004) Abundance of blue and humpback whales in the eastern north Pacific estimated by capture-recapture and line-transect methods. Marine Mammal Science 20(1):63-85.

Clapham, P.J. (2002) Humpback whale Megaptera novaeangliae. Pages 589-592 in Perrin, W.F., Würsig, B. And Thewissen H.G.M. (Eds) Encyclopedia of Marine Mammals. Academic Press, San Diego, CA, USA.

De la Cruz-Agüero, G. And Rodríguez-SÁnchez, R. (2000) Costas de México: Auxiliar para geo-referir localidades costeras en la República Mexicana. Programa version 1.5 y Manual del Usuario. CICIMAR - I.P.N. La Paz, B.C.S., México.

Evans, P. G. (1987) The natural history of Whales and Dolphins. Facts on file publications, New York, NY, USA.

Fleischer, L.A. AND Contreras U., J. (1986) Censos de ballenas grises (Eschrichtius robustus) en Bahia Magdalena, B.C.S., Mexico. Ciencia Pesquera (5):51-62.

Gardner, S.C. And Chávez-Rosales, S. (2000) Changes in the relative abundance and distribution of gray whales (Eschrichtius robustus) in Magdalena Bay, during an El Niño event. Marine Mammal Science 16(4):728-738.

International Whaling Comission (1986) Report of the Workshop. Pages 18-25 in Donovan, G. (Ed.) Behaviour of Whales in Relation to Management. Cambridge, United Kingdom.

Mangels, K.F. And Gerrodette, T. (1994) Report on cetacean sightings during a marine mammal survey in the Eastern Tropical Pacific ocean aboard the NOAA ships Mc Arthur and David Starr Jordan. July 28- November 2, 1992. NOAA Technical Memorandum NMFS. NOAA-TM-NMFS-SWFSC200. U.S Department of Comerce. National Oceanic and Atmospheric Administration. National Marine Fisheries Service. Southwest Fisheries Science Center.

Martin, A.R. And ReEves, R.R. (2002) Diversity and Zoogeography. Pages 1-37 in Hoelzel, A.R. (Ed.) Marine Mammal Biology an evolutionary approach. Blackwell, Oxford.

Ollervides, F.J. (2001) Gray whales and boat traffic: movement, vocal, and behavioral responses in Bahia Magdalena, Mexico. Ph. D. Thesis. Texas A\&M University, Galveston, TX, USA. 170pp.

Pérez-Cortés M., H., Urbán R., J. and Loreto C., P.A. (2004) A note on gray whale distribution and abundance in the Magdalena Bay Complex, México during the 1997 winter season. The Journal of Cetacean Research and Management 6(2):133-138.

Rice, D.W., Wolman, A.A., Withrow, D.E. And Fleischer, L.A. (1981) Gray whales on the winter grounds in Baja California. Reports of the International Whaling Commissionn 31: 477-489.

SCAMmON, C.M. (1874) The marine mammals of the north-western coast of North America. John H. Carmany and Company, San Francisco. Reprinted in 1968 by Dover Publications Inc., New York, NY, USA. 
Steiger, G.H., Calambokidis, J., Sears, R., Balcomb, K.C. and Cubbage, J.C. (1991) Movement of humpback whales between California and Costa Rica. Marine Mammal Science 7(3):306-310.

Urbán R., J. AND Aguayo L., A. (1987) Spatial and seasonal distribution the humpback whale, Megaptera novaeangliae, in the Mexican Pacific. Marine Mammal Science 3(4):333-344.

Urbán R., J., Alvarez F., C., Salinas Z., M., Jacobsen, J., Balcomb, K.C., Jaramillo L., A., Ladrón de Guevara P., P. and Aguayo L., A. (1999) Population size of humpback whale, Megaptera novaeangliae, in waters off the Pacific coast of Mexico. Fishery Bulletin 97: 1017-1024.

Urbán R., J., Jaramillo L., A., Aguayo L., A., Ladrón de
Guevara P., P., Salinas Z., M., Alvarez F., C., Medrano G., L., Jacobsen K., J., Balcomb, K.C., Claridge, D.E., Calambokidis, J., Steiger, G.H., Straley, J.M., von Ziegesar, O., Waite, J.M., Mizroch, S., Dahlheim, M.E., Darling, J.D. and BaKer., C.S. (2000) Migratory destinations of humpback whales wintering in the Mexican Pacific. Journal of Cetacean Research and Management 2:101-110.

Villa-Ramírez, B., Norris, K.S., Nichols, B., WÜrsig, B. and Miller., K. (1982) Agrupamientos de ballenas grises, Eschrichtius robustus (Lilljeborg, 1861) y entrada a las bahías en Baja California Sur, México, como estrategias alimentarias. Anales del Instituto de Biología Universidad Nacional Autónoma de México Serie Zoología 52(1):447-478. 